\title{
Correlated chemostratigraphy of Mn-carbonate microbialites (Úrkút, Hungary)
}

\author{
Márta Polgári a a,b,*, Tibor Németh a ${ }^{a}$, Elemér Pál-Molnár ${ }^{c}$, István Futó ${ }^{\mathrm{d}}$, Tamás Vigh ${ }^{\mathrm{e}}$, Stephen J. Mojzsis a,f,**

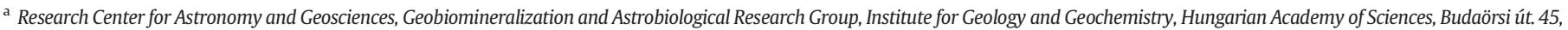 \\ 1112 Budapest, Hungary \\ b Eszterházy Károly College, Dept. of Natural Geography and Geoinformatics, Leányka str. 6, 3300 Eger, Hungary \\ c Szeged University, Dept. of Mineralogy, Geochemistry and Petrology, Egyetem str. 2-6, 6702 Szeged, Hungary \\ d Institute for Nuclear Research, Hungarian Academy of Sciences, Bem tér 18/c, H-4026 Debrecen, Hungary \\ e Mangán Ltd, Külterület 1, Úrkút 8409, Hungary \\ ${ }^{\mathrm{f}}$ Department of Geological Sciences, University of Colorado, 2200 Colorado Avenue, UCB 399, Boulder, CO 80309-0399, USA
}

\section{A R T I C L E I N F O}

\section{Article history}

Received 16 August 2014

Received in revised form 9 December 2014

Accepted 12 December 2014

Available online $\mathrm{xxxx}$

Handling Editor: R.D. Nance

\section{Keywords:}

Manganese carbonate

Sulfide

Trace elements

Microbialite

Jurassic

\begin{abstract}
A B S T R A C T
The genesis of a suite of Jurassic (Lias) microbialites at the Úrkút black shale-hosted manganese carbonate ore body (central Hungary) is described by a two-step microbial formation model that uses mineral chemistry combined with whole-profile (up section) textural context and sulfur isotopic compositions of associated pyrite and barite. Petrogenetic analysis and paleo-environmental reconstructions show that the sedimentary regime of the Úrkút microbialites mostly behaved as an open system during deposition of black shale under early diagenetic conditions. Sulfur isotopes and other chemostratigraphic indicators, however, reveal that the Mn ore bed horizons reached semi-closed/closed conditions which modulated sedimentation rate and organic matter burial. Barite horizons within Mn-carbonate layers preserve $\delta^{34} \mathrm{~S}_{\mathrm{VCDT}}$ values that average $+22.2 \%$, with a maximum at $+35.2 \%$. Barite formation occurred under semi-closed/closed conditions at diagenesis, and the Ba source is attributable to the decomposition of organic matter derived from plankton and other marine organisms, as well as transformation of biogenic silica. Pyritiferous horizons host equant, framboidal and euhedral morphotypes. The distribution and size of euhedral and framboidal sulfide habits is consistent with later diagenetic sulfate reduction under an oxic water column; more equant types occur at the contact zone of black shale and Mn-carbonate horizons. The microbialites of Úrkút bear strong similarities to ore bodies at Molango (Upper Jurassic, Mexico) and Tao Jiang (Middle Ordovician, China). Manganese supply and trace metal contents (Co, Ni, $\mathrm{Zn}, \mathrm{Cd}$ and As) of the sulfides also point to the effects of distal hydrothermal fluid sources to the system.
\end{abstract}

(c) 2014 International Association for Gondwana Research. Published by Elsevier B.V. All rights reserved.

\section{Introduction}

Authigenic Fe-sulfides are a common feature of fine grained, organic matter-rich marine sediments throughout the geologic record. They form under anoxic micro-conditions, where reactive organic matter, dissolved sulfate and reactive Fe-minerals co-mingle. As the relative contributions of these diverse components can vary in different sedimentary environments, their coupling with authigenic Fe-sulfides has long been used as an analytical geochemical facies indicator (e.g. Berner, 1980; Leventhal, 1983; Hámor and Hertelendi, 1991; Hámor, 1994; Vető et al., 1997). Sedimentary Fe-sulfides principally form during early diagenesis in the sulfate reduction zone, and because of this they are a reliable testimony of pore water chemistry (e.g. Sweeney and

\footnotetext{
* Corresponding author.

** Correspondence to: S.J. Mojzsis, Department of Geological Sciences, University of Colorado, 2200 Colorado Avenue, UCB 399, Boulder, CO 80309-0399, USA.

E-mail addresses: rodokrozit@gmail.com (M. Polgári), palm@geo.u-szeged.hu (E. Pál-Molnár), futo@atomki.mta.hu (I. Futó), manganvigh@vnet.hu (T. Vigh), mojzsis@colorado.edu (S.J. Mojzsis).
}

Kaplan, 1973; Hudson, 1982; Raiswell, 1982). Pyrite framboid size distribution is also a representative primary feature of anoxic sediments. Syngenetic framboids formed in euxinic water columns are on average smaller and less variable in size than those diagenetically formed in sediments underlying oxic water columns (Wilkin et al., 1996, 1997). Together with other chemical features that we highlight below, they are a useful tool in recording changes to bottom-water redox conditions (Wilkin et al., 1997; Wignall and Newton, 1998).

Sulfur isotopic values of authigenic marine Fe-sulfides - sometimes associated with sulfates in carbonates - are often used to interrogate the evolution of the marine chemical system, and in particular the long term changes in oceanic sulfate content and a sulfur isotope composition (e.g. Holland, 1978). One such integrated example is the known occurrence of pyrite-bearing horizons within microbially-mediated laminated Mn-carbonate sediments. Despite the fact that such rocks have been widely documented in Phanerozoic marine sediments (e.g. Molango, Mexico - Okita and Shanks, 1988; Moanda, Gabon - Hein et al., 1989; Postmasburg, Southwest Africa - Beukes, 1983; Taojiang-MinleDatangpo, China - Fan et al., 1999; Úrkút, Hungary - Polgári et al., 1991, 2012a), models for their genesis are under debate. There are 
two competing models for Mn-carbonate mineralization in marine basins (as reviewed in Maynard, 2010): (i) the so-called "bath-tub ring" or euxinic basin model of Force and Cannon (1988), which has been applied, for example, to the Molango and TaoJiang localities cited above; and (ii) the Oxygen Minimum Zone model (Calvert and Pedersen, 1993), which presents an alternative to the euxinic basin idea and argues for deposition in the open ocean. It is noteworthy that although such ores are both economically important and of world-wide occurrence, no examples are known to exist in the contemporary marine system. Furthermore, despite a range of ages, the various deposits cited above are broadly similar to one another. A common feature they share is fine grained and "crinkly" organic matter-rich microlaminae generally conformable with bedding, typical for microbialites.

At the Úrkút locality in central Hungary, several (1-3) meter-scale Mn-carbonate beds occur in a ca. 50 m thick black shale. Mineralogical compositions (rhodochrosite, smectite, celadonite, siderite, manganite, goethite, hematite) and isotopic characteristics (strongly depleted $\delta^{13} \mathrm{C}$ values) of these ores are also distinctive to the ore body (reviewed in Okita and Shanks, 1988; Hein et al., 1989; Polgári et al., 1991; Fan et al., 1999). It was previously argued that such stratiform sedimenthosted Mn-carbonate ore deposits exclusively formed in strictly closed systems (Okita and Shanks, 1992; Fan et al., 1999). Most of the blackshale hosted Mn-carbonates are so well-preserved (Fan et al., 1999) that their morphological characteristics such as crinkly bedding can be directly compared to microbially-induced sedimentary structures; in this work we describe them as microbialites (sensu lato). Improvements on the general basin models for their deposition, along with the detailed mineralogical and geochemical studies cited above, further bolster the view that Mn-carbonate ores within black shale-hosted deposits in Molango Mexico (Okita et al., 1988); Úrkút, Hungary (Polgári et al., 1991); and Taojiang-Minle-Datangpo-China (Fan et al., 1999) are microbialites.

To explore these relationships further in the context of microbiallymediated sedimentary processes, we undertook a detailed study of the textural and trace element contents (e.g. As) of selected pyrite-bearing samples of one of the best examples of a Mn-carbonate deposit at the Mesozoic Úrkút locality in central Hungary (reviewed in Polgári et al.,
2003). Here, we report on the geology and geochemistry of the Úrkút Mn-carbonate ores in comparison with analogous ore deposits, and use these data to construct a model for their genesis that accounts for their microbialite nature. This paper builds on a recently elaborated two step microbial formation model (Polgári et al., 2012a) for the genesis of the Úrkút rocks and uses the model to shed new light on the formation of similar ores elsewhere in the geologic record (e.g. Taojiang, China).

\section{Geological setting}

The Jurassic Úrkút deposit is of Toarcian age (Falciferum ammonite zone viz. Géczy, 1973) and is located in the Transdanubian Range in central Hungary, approximately $150 \mathrm{~km}$ west of Budapest (Fig. 1). It is, volumetrically, among the ten largest of its kind. Estimated reserves are about 80 million tons of Mn-carbonate ore that averages 20 wt.\% $\mathrm{Mn}$ and $10 \mathrm{wt} . \% \mathrm{Fe}$, with an areal extent of tens of square kilometers. The Úrkút deposit occurs within marine sedimentary rocks composed mainly of bioclastic limestone, radiolarian clay marlstone and dark-gray to black shale. Rhodochrosite beds conformably overlie middle Lias (lower Jurassic) cherty limestone. The ore is composed of laminated, alternating gray, green, brown, and black sections composed of mixtures of fine-grained carbonate minerals and clays. The very fine-grained (1-2 $\mu \mathrm{m})$ rhodochrosite-bearing sediments lack detrital grains (Polgári et al., 2012a), and it was argued that ore accumulation took place in a structurally controlled small marine basin in a low-energy and low-temperature depositional environment. The deposit is unmetamorphosed; it was not affected by any significant diagenetic thermal overprinting as shown by oxygen isotope data, and probably experienced temperatures ranging between 17 and $23^{\circ} \mathrm{C}$ at the time of formation (Polgári et al., 2012a).

The deposit consists of three Mn ore beds (10-, 3-, and $1 \mathrm{~m}$ thick) separated by a 20 - and 4 m-thick black shale (Fig. 2). The genetic model of Polgári et al. (2012a) proposed that two cycles of microbial activity triggered ore formation: Cycle 1 (syngenetic) was an aerobic chemolithoautotrophic cycle that sequestered metal ions $\left(\mathrm{Mn}^{2+}, \mathrm{Fe}^{2+}\right)$ from solution via $\mathrm{Mn}$ (II) oxidation at the sediment/water interface. Under this scenario, Mn-oxides were deposited in the sediment pile,

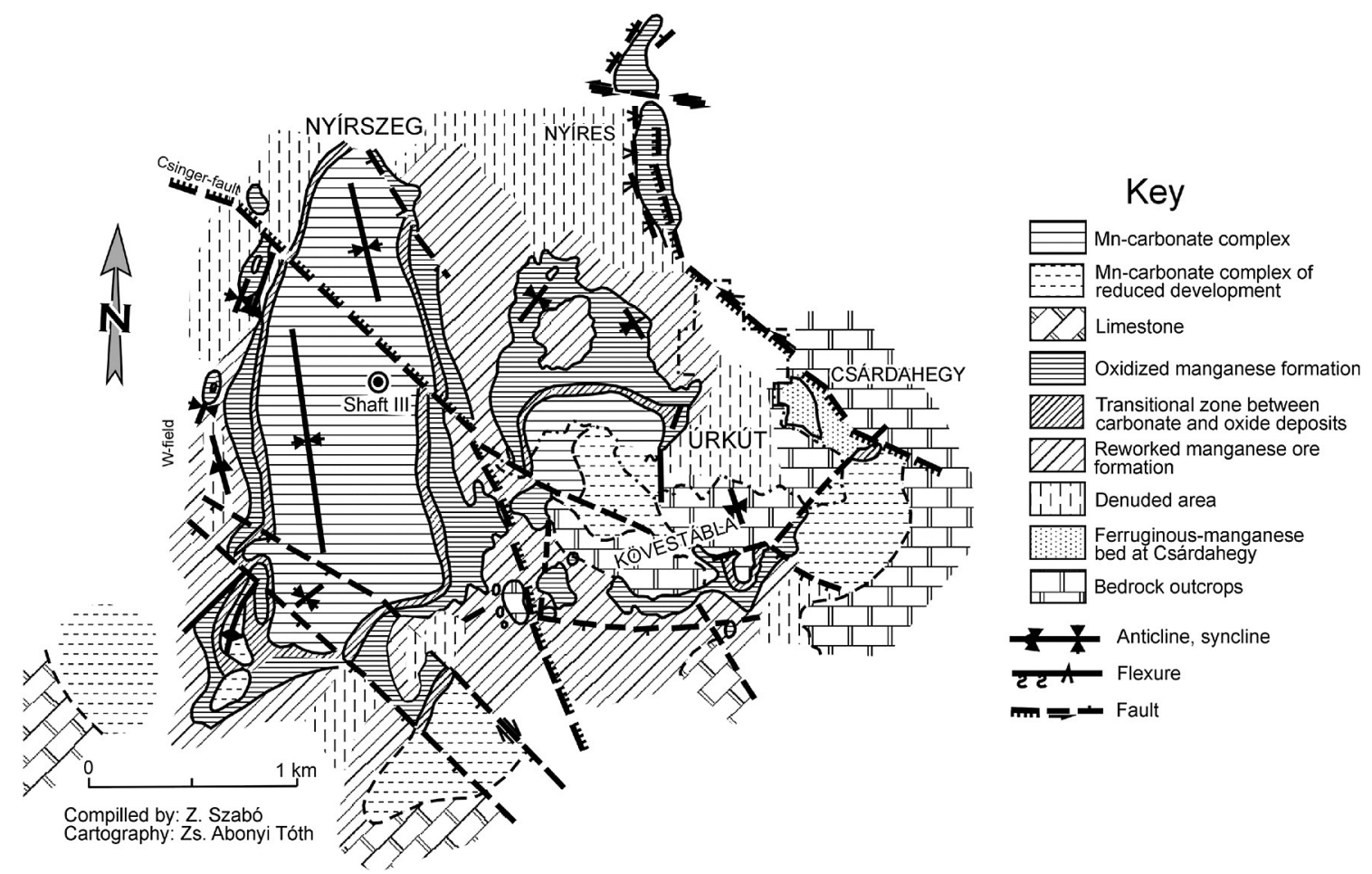

Fig. 1. Geological sketch map of the Úrkút manganese deposit (after Szabó and Grasselly, 1980). Locality GPS data are: $47^{\circ} 04^{\prime} 55^{\prime \prime} \mathrm{N}$ and $17^{\circ} 38^{\prime} 40^{\prime \prime} \mathrm{E}$. 
thus also serving as a paleoenvironmental indicator of oxic conditions. Cycle 2 (diagenetic) was an anaerobic/suboxic heterotrophic microbial cycle where early diagenetic microbially-mediated Mn(IV) and Mn(III) reduction took place via organic matter oxidation and Mn-carbonate mineralization (Polgári et al., 1991, 2012a). The ore sequence is laminated at the millimeter scale, and this fabric was interpreted to represent a series of Fe-rich microbially-induced sedimentary structures or biomats (Polgári et al., 2012b).

\section{Samples and methods}

Powder diffraction on 62 samples (258 subsamples) was performed using a Philips X-ray diffractometer (PW 1710) with carbon monochromator and $\mathrm{Cu} \mathrm{K} \alpha$ radiation. Mineral composition was determined on randomly oriented powdered samples by semi-quantitative phase analysis according to the modified method of Bárdossy et al. (1980), using previously defined intensity factors.

Oriented samples $(\mathrm{n}=112$ ) were collected along a $917 \mathrm{~cm}$ thick section from the footwall to hanging wall from four sections that cross the main ore bed, and two section crossing the upper ore bed (Fig. 2). Bulk and separated lamina sub-samples were examined to determine macroscopic features that cause color and grain-size variations. Petrographic structural-textural studies were made on ninety oriented (bottom and top of sample position) thin sections in transmitted and reflected light modes.

Samples earmarked for sulfur isotopes were chosen based on mineralogy and thin section observations (pyrite and barite occurrences; Fig. 2). The pyrite- and/or barite-bearing samples, their characterization and the methods used, as well as $S$ isotope data reported in the standard delta notation $\left(\delta^{34} \mathrm{~S}_{\mathrm{VCDT}}\right)$ are summarized in Table 1.

Our ${ }^{34} \mathrm{~S} /{ }^{32} \mathrm{~S}$ measurements used the quantitative "Dynamic Flash Combustion" method. Sulfur measurements were made with a Flash Elemental Analyzer (single reactor filled with $\mathrm{CuO}$ and copper wires). A magnesium perchlorate chemical trap removes the water produced in the combustion process. An elemental analyzer NA 1500 NCS Fisons Instruments and Thermo Finnigan ConFlo III system at the Institute for Nuclear Research (HAS, Debrecen, Hungary) combines the high precision of classical multiple sample/standard comparison technique with the ease and sensitivity of an on-line interface. The analyte gas $\left(\mathrm{SO}_{2}\right)$ from the quantitatively combusted inorganic material was introduced by the ConFlo III system to a Thermo Finnigan DELTA ${ }^{\text {plus }} \mathrm{XP}$ isotope ratio mass spectrometer. This continuous flow technique allows automated isotope ratio determination of small gas samples. The $\mathrm{S}$ replicate analyses agreed within $\pm 0.5 \%$.

Quantitative electron microscopy studies of samples were made on carbon-coated thin sections (Table 1) using a JEOL Superprobe 733 microprobe equipped with Oxford INCA 2000 energy-dispersive X-ray spectrometer at the Institute of Geology and Geochemistry (HAS, Budapest). Analytical conditions were $20 \mathrm{kV}$ accelerating voltage and $5 \mathrm{nA}$ beam current.

\section{Results}

\subsection{Bulk mineralogy and average chemistry}

Bulk and subsample mineral compositions of the Mn-carbonate profiles are summarized in Fig. 3.

The minerals within the samples are typically microcrystalline, averaging $1-2 \mu \mathrm{m}$ in size, with very rare detrital mineral grains up to several tens of micrometers in diameter (e.g. quartz). The bulk mineralogical composition of the Mn-carbonate ore beds is dominated by rhodochrosite (Ca-, Mg-bearing), siderite (second bed), kutnohorite, celadonite, smectite (nontronite), goethite, quartz, Ca-apatite (phosphorite) and pyrite, with traces of barite, chlorite, zeolite, feldspar, and manganite. The black shale host consists of quartz, calcite, pyrite, smectite, illite, celadonite, goethite, and chlorite, with traces of zeolite, and feldspar. Manganite is the only Mn oxide present in the carbonate-ore bed.

Pyrite occurs commonly in the black shale horizons (underlying-b1, middle-b2, overlying-b3, b4), in the first ore sample, and in the middle and upper parts of the main (i.e. first) ore bed (Polgári, 1993; Polgári et al., 2003). The second and third ore beds are characterized by alternating thin ore and black shale layers, which are macroscopically not distinguishable. Barite occurs in profile 4 in the middle part of the main ore bed. The average main and trace element composition according to ore types and black shale is summarized in Polgári et al. (2012a), which is similar to that calculated here based on mineralogy. The organic matter content in the black shale is around $4 \mathrm{wt} . \%$ - in the Mn carbonate ore beds it is around $0.5 \mathrm{wt} . \%$, the S content ranges between 0.06 and $11.67 \mathrm{wt} . \%$, and the Ba content between $123 \mathrm{ppm}$ and $1.5 \mathrm{wt}$.\% based on bulk analyses (Polgári et al., 2012a).

\subsection{Morphology}

\subsubsection{Pyrite}

Euhedral, framboidal and/or equant-type pyrites occur rarely in the ore, and when they do it is at the contact of underlying black shale and first ore sample, and top of the main Mn carbonate ore bed. Sulfides are frequently found in the black shale horizons (b1, 2, 3, 4; Table 1, Fig. 4).

Euhedral, mainly cubic and/or octahedral pyrites range in size from $\sim 0.5$ to $5 \mu \mathrm{m}$, and up to $10-30 \mu \mathrm{m}$. Framboidal pyrite grains tend to be smaller $(0.5-1 \mu \mathrm{m})$ and form $30-50 \mu \mathrm{m}$ clusters that when clustered together are several hundred micrometers across. Equant type pyrites $(>20 \mu \mathrm{m})$ are similar to the euhedral and framboidal forms and are often concentrated in layers and lenses.

The underlying black shale (b1), as well as the contact with the main ore bed and b1 (Fig. 5A), is characterized by equant and xenomorphic pyrite. Most of the main Mn-carbonate ores are not pyritiferous, but the upper part of profile 4 (4/24-28) contains pyrite in $\mathrm{C}_{\text {org }}$-rich lenses and as pyritized Fe-rich zones that we interpret to have been goethitic biomats (Fig. 4A, B). The lower section of profile 5 is more pyritiferous and is rich in euhedral and equant type forms (5/1-7). The top of the main ore bed $(5 / 9,13-14$, gray type ore) is even more pyrite-rich, with massive pyrite layers also occurring there (Figs. 4C, D, 5B). Equant type pyrites are the most frequent habit in this sample set (Fig. 4G, H). The middle black shale (b2) between the main and second ore beds likewise contains framboidal and euhedral pyrite, and the second bed is characterized by equant and euhedral forms (5/15-19). The b3 and b4 horizons are similar to b2.

\subsubsection{Barite}

Barite is not visible by conventional optical microscopy; its presence was revealed by X-ray diffraction and SEM-EDS. Analytical electron microscopy was used to investigate the morphology and trace element content of this mineral. Barite occurs in the lower-middle part of the main ore bed, in profile 4 (4/6, 9, 9b, 10a, 16a, 18, 20, 21, 22, 23, upper green ore type). The Ba content ranges from 123 ppm to 1.5 wt.\% (Polgári et al., 2012a).

Barite is present as (i) disseminated small xenomorphic or semieuhedral grains $(0.5-20 \mu \mathrm{m}$, most frequently $1-5 \mu \mathrm{m}$, Fig. 5C-G); and (ii) in layers among Fe-rich biomat laminae, surrounded by Ca-rich rhodochrosite and clay bearing matrix (Fig. 5E, F, G). It is noteworthy that barite in our samples is always accompanied by quartz (Fig. 5E, F). Barite vein fillings are also found, which points to complex remobilization processes.

\subsection{Chemical composition of pyrite and barite}

Compositionally, pyrite in our samples is generally pure and homogenous, but in some layers $\mathrm{Fe}-\mathrm{Co}(\mathrm{Ni})$-sulfide is also present as well as arsenic-bearing pyrite (b1, upper part of main ore bed).

Barite is pure Ba-sulfate, but in the brown, upper green and gray type main ore beds and in vein fillings, it is occasionally enriched in Sr. 
M. Polgári et al. / Gondwana Research xxx (2014) xxx-xxx

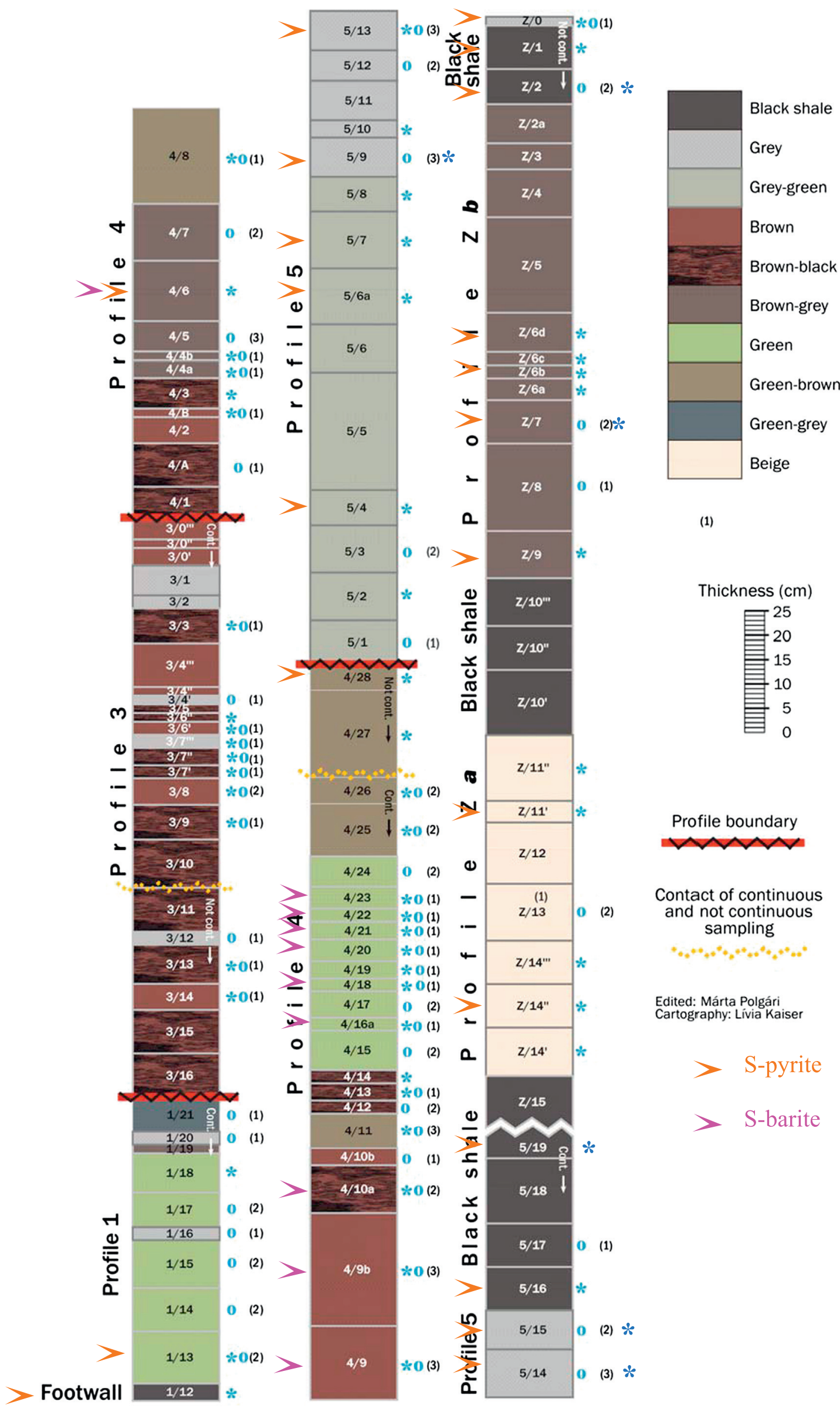




\subsubsection{Sulfur isotopes}

Sulfur isotope values and distribution in the ore profile are presented in Table 1 and Figs. 2 and 6 for pyrite and barite. These results show that: (i) the underlying black shale (sample $1 / 12$ ) has a $\delta^{34} \mathrm{~S}$ value of $-14.7 \%$; (ii) the lower and middle parts of the Mn-carbonate main ore bed (profiles $1,2,3$, and 4, samples 4/9-6-4/23) contain only barite with a $\mathrm{S}$ isotope range between $+2.0 \%$ and $+27.2 \%$. As an exception, in the first ore sample $(1 / 13)$ there is pyrite with $\delta^{34} \mathrm{~S}-8.3 \%$. In the middle part of the main Mn carbonate ore bed, sample 4/6 contains both pyrite and barite (the only sample which contains both minerals, but in different sublayers), and the pyrite $\delta^{34} \mathrm{~S}$ value is $+3.0 \%$, and the barite is $+14.6 \%$. The samples above it contain only barite (Fig. 2 ), but just below profile 5 , sample $4 / 28$ is also pyritiferous with $\delta^{34} \mathrm{~S}$ value of $+8.7 \%$ o (pyritized biomat, Fig. $4 \mathrm{~A}, \mathrm{~B}$ ); (iii) the upper part of the main Mn carbonate ore bed (profile 5, samples 5/1/1-5/14/3, Fig. 2 ) is pyritiferous with a $S$ isotope range of -7.8 to $+35.2 \%$; (iv) the middle black shale $(5 / 15-5 / 19)$ is also pyritiferous with $S$ isotope values between -24.3 and $-20.3 \%$ o ( -10.7 to $-23.4 \%$ o was reported for this horizon by Vetö et al., 1997); (v) the second Mn carbonate ore bed is interfingered by black shale and it is difficult to distinguish macroscopically the two facies because the transition is continuous. The second carbonate bed $(\mathrm{Z} / 14-\mathrm{Z} / 6 \mathrm{D})$ contains pyrite with $\mathrm{S}$ isotopes that range from -0.8 to $-17.9 \%$; (vi) the top black shale $(\mathrm{Z} / 2-\mathrm{Z} / 1$ ) bed has $\mathrm{S}$ isotopes between -31.4 and $+17.1 \%$; (vii) the top-most Mn-carbonate ore layer $(\mathrm{Z} / 0 / 1)$ has $\delta^{34} \mathrm{~S}$ of $+8.4 \%$.

\section{Discussion}

\subsection{Sulfur isotopes and clues to the genesis of Úrkút pyrite}

For the most part, the Úrkút Mn-carbonate deposit is pyrite free. In the ore zones, organic matter alteration took place via microbiallymediated $\mathrm{Mn}(\mathrm{IV}, \mathrm{III})$ reduction, and the system did not reach the sulfate reduction zone; it remained suboxic (Polgári et al., 2012a, 2013). The pyrite-bearing zones are within the black shales toward the top of the sequence. Distribution of euhedral and framboidal pyrite habits in the black shale of the ore profile supports later diagenetic sulfate reduction zones, whereas equant types are present at the contact zone of the underlying b1 and the main ore bed defined by the start of the main Mn mineralization stage (samples $1 / 12$ and 1/13), the upper gray part of the main ore bed toward b2 (termination of main Mn mineralization period; samples $5 / 9,13,14,15$ ), and the second ore bed (start of the second $\mathrm{Mn}$ mineralization period; sample Z/0).

Framboidal pyrite is formed via recrystallization of precursor Fe-monosulfide, whereas the euhedral grains precipitated directly from solution at low $\mathrm{pH}$. Growth of both framboidal and euhedral types occurs when the diffusive supply is faster than the rate at which the crystal structure can accommodate Fe-S (based on saturation-middle oversaturation; Murowchick and Barnes, 1987). During pyrite formation, the in situ conditions of saturation are supplied from the overlying sediment via reduction to sulfide of a continuous sulfate supply (Fig. 6), as described by Vető et al. (1997). During diagenetic development in sediment pore waters, framboidal pyrite first forms in an open system characterized by considerable enrichment of ${ }^{32} \mathrm{~S}$ (strongly negative $\delta^{34} \mathrm{~S} \%$ o values; b1, 2, 3 and 4, Fig. 6). The size of framboids supports diagenetic formation in the sulfate reduction zone under an oxic water column as described in Wilkin et al. (1996, 1997). Subsequently, euhedral pyrite forms when the pore volume and the diffusive supply of $\mathrm{Fe}-\mathrm{S}$ decrease so the system becomes closed. As such, the $\mathrm{S}$ isotope values become more enriched in ${ }^{34} \mathrm{~S}$ leading to slightly negative or increasingly positive $\delta^{34} \mathrm{~S} \%$ o values, respectively. The Úrkút sedimentary system behaved as an open system throughout most of the black shale accumulation and early to late diagenesis. This view is supported by the $\delta^{34} \mathrm{~S}$ values cited above. Ore horizons reached semi-closed/closed conditions with relatively more positive $\delta^{34} \mathrm{~S}$ values than contemporaneous Jurassic seawater at around $+16 \%$ 。 during diagenesis (Claypool et al., 1980; Table 1, Fig. 6). The Mn carbonates contain enriched values of ${ }^{34} \mathrm{~S}$ with an average of $+22.2 \%$ 。 (maximum is $+35.2 \%$ ).

Equant type pyrites differ in origin and composition from the framboids and euhedral types. Under conditions of extreme oversaturation they precipitate directly from solution and frequently outgrow the pore space, inducing local soft-sediment deformation. Based on these features, the equant type pyrite most probably formed via external pore fluid migration. Sulfur isotope values of the equant type pyrites are also different; they can be very enriched or depleted in ${ }^{32} \mathrm{~S}$ depending on the origin of fluid migration. The Úrkút data are strongly negative and moderately positive in $\delta^{34} \mathrm{~S}(-20.3$ to $+20.8 \%$; Table 1 ; Fig. 6$)$. Sulfate reduction results in enrichments in ${ }^{32} \mathrm{~S}$, and hydrothermal effects tend to drive $\delta^{34} \mathrm{~S}$ toward heavier values. Perhaps the most important factor to influence the sulfur isotope signature of sedimentary pyrites is the rate of sediment accumulation because this determines whether the system is open or closed. In the case of Úrkút, mass balance calculations show that the sedimentation rate was very high (Polgári et al., 2012a).

\subsection{S isotope interpretation and genetic considerations of barite}

Barite occurs in the lower-middle part of the main ore bed, in profile 4 (upper green ore type), with a $\delta^{34} \mathrm{~S}$ value between +2.0 and $+27.2 \%$ 。 and an average value of $+14.2 \%$. Taking into consideration that Jurassic seawater $\delta^{34} \mathrm{~S}$ was around $+16 \%$, shows that barite formation occurred most probably under a microbially mediated semi-closed/ closed system during later diagenesis. Barite is a common authigenic constituent of marine sediments (e.g. Rothewell, 1989), in the form of disseminated small grains as in Úrkút, enriched in lenses or layers, and commonly associated with biogenic debris (Cruickshank, 1974; Clark et al., 1990).

Hydrothermal activity can also be invoked as a source for Ba because Fe and Mn contents are high (Mn-Fe ore), and vein filling Sr-bearing barite bolsters this possibility. Volcanic debris (e.g. ash) alteration as source for Ba can be excluded, as it has previously been shown that there was no volcanogenic contribution to the deposit (Polgári et al., 2013). A clear association exists, however, between barite and organic matter as previously reported by Boström et al. (1973). The Úrkút barite is also commonly associated with quartz like that noted by Stamatakis and Hein (1993) who proposed that the barite was derived from the diagenesis of biogenic silica. According to Stamatakis and Hein (1993), the formation of authigenic quartz preceded the formation of barite. The source of Ba, therefore, was most likely via decomposition of organic matter derived from plankton and other organisms (Radiolaria), and the diagenesis of biogenic silica. This scenario also fits well with the disseminated, plankton-derived formation model presented by Koski and Hein (2004). The source of the sulfate ions was from seawater and possibly additional sulfate was produced and utilized in microenvironments from the decomposition of organic matter. Aqueous barium and sulfate most commonly combined as an abiogenic precipitate within void space generally within organic-rich parts of the sediment. In marine sediments, barite precipitation can be initiated by increasing sulfate or Ba activity or by changes to $\mathrm{pH}$ associated with the decay of organic matter (Clark and Mosier, 1989; Maynard and Okita, 1991) and the

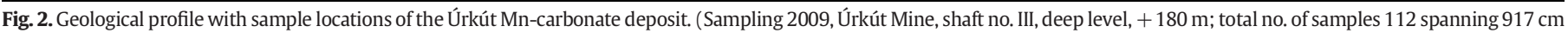

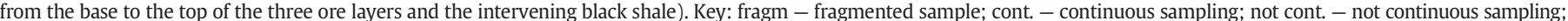

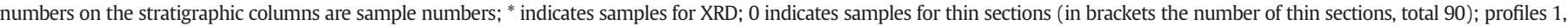

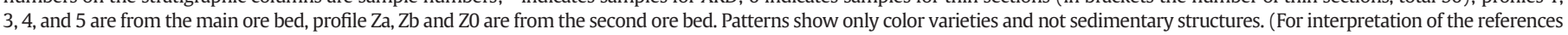
to color in this figure legend, the reader is referred to the web version of this article.) 
Table 1

Selected samples of ore profile based on pyrite and barite occurrences (XRD and/or thin section study), and S isotope data, morphology and chemistry.

\begin{tabular}{|c|c|c|c|c|c|c|c|c|c|c|c|}
\hline System & $\begin{array}{c}\text { Bs effect } \\
\text { pore fluid } \\
\text { migration } \\
\text { (microbial } \\
\left.\mathrm{H}_{2} \mathrm{~S}\right)\end{array}$ & $\begin{array}{c}\delta^{34} S \\
\text { Pyrite } \\
(\%)\end{array}$ & Sample & $\begin{array}{c}\delta^{34} S \\
\text { Barite } \\
(\%)\end{array}$ & XRD & $\begin{array}{l}\text { Thin } \\
\text { section }\end{array}$ & $\begin{array}{l}\text { SEM- } \\
\text { EDS }\end{array}$ & $\begin{array}{l}\text { Size of } \\
\text { pyrite } \\
(\mu \mathrm{m})\end{array}$ & $\begin{array}{l}\text { Morphology } \\
\text { of pyrite }\end{array}$ & $\begin{array}{c}\text { Occurrence } \\
\text { characteristics }\end{array}$ & Chemistry \\
\hline Open & $\begin{array}{l}\overrightarrow{\text { Hydr }} \\
\text { effect? }\end{array}$ & +8.4 & $\mathrm{Z} / 0 / 1$ & & & $*$ & $*$ & $\sim 50$ & $\mathrm{Eq}+\mathrm{E}^{*}$ & $\begin{array}{l}\text { Random } \\
\text { sheaf-like sets }\end{array}$ & \\
\hline Open & & & & & & & $*$ & $0.5-1$ & $\mathrm{E}$ & $\begin{array}{l}\text { Random, } \\
\text { dissem* }\end{array}$ & \\
\hline Open & & +5.3 & $\mathrm{Z} / 1-2^{*}$ & & $*$ & & & & & & \\
\hline Open & & $+17-1$ & $\mathrm{Z} / 1-1$ & & $*$ & & & & & & \\
\hline Open & & -31.4 & $\mathrm{Z} / 2 / 2$ & & $*$ & $*$ & * & $\begin{array}{l}0.5-1 \\
(<50)\end{array}$ & $\mathrm{F}^{*}$ & Random, dissem & \\
\hline Open & & & & & & & $*$ & $0.5-1$ & $\mathrm{E}$ & $\begin{array}{l}\text { Random, } \\
\text { disseminated }\end{array}$ & \\
\hline Open & $\rightarrow$ & -17.0 & $\mathrm{Z} / 6 \mathrm{D}$ & & $*$ & & & & & & \\
\hline Open & $\rightarrow$ & -17.0 & Z/6B-1 & & $*$ & & & & & & \\
\hline Open & & -5.0 & $\mathrm{Z} / 7 / 2$ & & $*$ & & & $\begin{array}{l}0.5-1 \\
(<50)\end{array}$ & $\mathrm{F}$ & Random & \\
\hline Open & & & & & & & & $0.5-1$ & $\mathrm{E}$ & $\begin{array}{l}\text { Thin and } \\
\text { thicker layers } \\
\text { (laminae) }\end{array}$ & \\
\hline Open & & - & $\mathrm{Z} / 8 / 1$ & & - & $*$ & $*$ & $\begin{array}{l}0.5-1 \\
(10-20)\end{array}$ & $\mathrm{F}$ & $\begin{array}{l}\text { Disseminated, } \\
\text { random }\end{array}$ & \\
\hline Open & & & & & & & * & $0.5-1$ & $\mathrm{E}$ & $\begin{array}{l}\text { Along layers } \\
\text { (laminae), at } \\
\text { some places } \\
\text { very rich }\end{array}$ & \\
\hline Open & & & & & & & * & $0.5-1$ & $\mathrm{E}$ & $\begin{array}{l}\text { Real pyrite-rich } \\
\text { layer (thickness } \\
\text { is ca: } 500 \mu \mathrm{m} \text { ) }\end{array}$ & \\
\hline Open & & -17.4 & $\mathrm{Z} / 9$ & & $*$ & & & & & & \\
\hline Open & & -17.9 & $\mathrm{Z} / 11$ & & $*$ & & & & & & \\
\hline Open & $\rightarrow$ & - & $\mathrm{Z} / 13 / 2$ & & - & $*$ & & $0.5-1$ & E & $\begin{array}{l}\text { Disseminated + } \\
\text { clusters (lenses) } \\
\text { in altered Corg- } \\
\text { rich parts }\end{array}$ & \\
\hline Open & $\rightarrow$ & -0.8 & $\mathrm{Z} / 14$ & & $*$ & & & & & & \\
\hline Open & & -24.3 & $5 / 19$ & & $*$ & & & & & & \\
\hline Open & & -22.5 & $5 / 16$ & & $*$ & & & & & & \\
\hline Open & $\rightarrow$ & -20.3 & $5 / 15 / 2$ & & $*$ & $*$ & $*$ & 20-30- & $\begin{array}{l}E q+E+F \\
4-, 6-\end{array}$ & $\begin{array}{l}\text { Different types are } \\
\text { separated by } \\
\text { sedimentary } \\
\text { horizons, at some } \\
\text { zones strong } \\
\text { enrichment, thin } \\
\text { and thicker layers } \\
\text { up to some hundred } \\
\mu \mathrm{m}\end{array}$ & \\
\hline Open & $\rightarrow$ & & & & & & $*$ & $\begin{array}{l}50(50- \\
200)\end{array}$ & $E q+E+F$ & $\begin{array}{l}\text { Different types } \\
\text { are separated by } \\
\text { sedimentary } \\
\text { horizons, at some } \\
\text { zones strong } \\
\text { enrichment, thin } \\
\text { and thicker layers } \\
\text { up to some hundred } \\
\mu \mathrm{m}\end{array}$ & \\
\hline Open & $\rightarrow$ & +7.3 & $5 / 14 / 3$ & & $*$ & $*$ & $*$ & $50-80$ & $E q+E$ & $\begin{array}{l}\text { In layer equant } \\
\text { pyrite (twins?) } \\
\text { with core which } \\
\text { are homogenous } \\
\text { by EDS }\end{array}$ & $\begin{array}{l}\text { Secondary } \\
\text { barite } \\
\text { veinlets } \\
\text { randomly } \\
\text { Sr-bearing }\end{array}$ \\
\hline Open & $\rightarrow$ & & & & & & $*$ & $0.5-1$ & E & $\begin{array}{l}\text { Layers, lenses } \\
\text { alternate or } \\
\text { disseminated }\end{array}$ & \\
\hline
\end{tabular}


Table 1 (continued)

\begin{tabular}{|c|c|c|c|c|c|c|c|c|c|c|c|}
\hline Open & $\rightarrow$ & & & & & & $*$ & $10-20$ & $E q+E$ & $\begin{array}{l}\text { Layers, lenses } \\
\text { alternate or } \\
\text { disseminated }\end{array}$ & \\
\hline Open & $\rightarrow$ & & & & & & * & Massive & $\mathrm{M}^{*}$ & & \\
\hline Open & $\rightarrow$ & -7.8 & $5 / 13 / 1$ & & * & * & $*$ & Massive & M & Massive part & $\begin{array}{l}\text { ZnS (Cd), } \\
\mathrm{Ce}(\mathrm{La} \text {, } \\
\text { Nd, Ca)- } \\
\text { phosphate } \\
\text { top of main } \\
\text { ore bed }\end{array}$ \\
\hline Open & & & & & & * & $*$ & $10-20$ & $\mathrm{Eq}$ & Disseminated & \\
\hline $\begin{array}{l}\text { Semi- } \\
\text { closed/ } \\
\text { closed }\end{array}$ & $\begin{array}{l}\text { Hydr } \\
\text { effect? }\end{array}$ & +20.8 & $5 / 9 / 3$ & & * & $*$ & * & $10-30$ & $E q+E$ & $\begin{array}{l}\text { Disseminated, } \\
\text { frequent }\end{array}$ & $\begin{array}{l}\text { Pyrite rich } \\
\text { layers also }\end{array}$ \\
\hline $\begin{array}{l}\text { Semi- } \\
\text { closed/ } \\
\text { closed }\end{array}$ & & & & & & & * & $\begin{array}{l}0.5-1 \\
(20-30)\end{array}$ & $\mathrm{F}$ & Rare & \\
\hline $\begin{array}{l}\text { Semi- } \\
\text { closed/ } \\
\text { closed }\end{array}$ & & & & & & & $*$ & $20-50$ & $\mathrm{Eq}(6-)$ & $\begin{array}{l}\text { Rare, also in } \\
\text { layer }\end{array}$ & $\begin{array}{l}\text { Finer } \\
\text { upstairs }\end{array}$ \\
\hline Open & & +3.8 & $5 / 7$ & & * & & & & & & \\
\hline Open & & +16.8 & 5/6a-9 & & $*$ & $*$ & * & & & & \\
\hline $\begin{array}{l}\text { Semi- } \\
\text { closed/ } \\
\text { closed }\end{array}$ & & +22.2 & $5 / 6 a-4$ & & $*$ & $*$ & $*$ & & & & \\
\hline $\begin{array}{l}\text { Semi- } \\
\text { closed/ } \\
\text { open }\end{array}$ & & +17.3 & $5 / 6 a-3$ & & $*$ & $*$ & $*$ & & & & $\begin{array}{l}\text { As-bearing } \\
\text { pyrite }\end{array}$ \\
\hline $\begin{array}{l}\text { Semi- } \\
\text { closed/ } \\
\text { open }\end{array}$ & & +23.5 & $5 / 6 a-2$ & & $*$ & * & $*$ & & & & \\
\hline $\begin{array}{l}\text { Semi- } \\
\text { closed/ } \\
\text { closed }\end{array}$ & & +35.2 & $5 / 4-11$ & & $*$ & & & & & & \\
\hline \multirow{2}{*}{$\begin{array}{l}\text { Semi- } \\
\text { closed/ } \\
\text { closed }\end{array}$} & & +33.4 & $5 / 4-10$ & & * & & & & & & \\
\hline & & - & $5 / 1 / 1$ & & & $*$ & & $0.5-1$ & $\mathrm{E}$ & $\begin{array}{l}\text { Disseminated, } \\
\text { and in lenses }\end{array}$ & \\
\hline \multirow[t]{19}{*}{ Open } & & +8.7 & $4 / 28$ & & $*$ & & & & & & \\
\hline & & & $4 / 26$ & & $*$ & $*$ & & $1-5 ?$ & $\mathrm{E}$ & $\begin{array}{l}\text { Pyritized } \\
\text { biomat }\end{array}$ & \\
\hline & & - & $4 / 24 / 2$ & & & * & & $1-10$ & $E+M$ & $\begin{array}{l}\text { Random in } \\
\text { lenses }\end{array}$ & \\
\hline & & & $4 / 23$ & +26.2 & $*$ & $*$ & & & & & \\
\hline & & & $4 / 22-3$ & +11.7 & $*$ & $*$ & * & & & & \\
\hline & & & $4 / 22-1$ & +27.2 & $*$ & $*$ & $*$ & & & & \\
\hline & & & $4 / 21-7$ & +4.5 & $*$ & $*$ & $*$ & & & & \\
\hline & & & 4/21-6 & +2.0 & $*$ & $*$ & $*$ & & & & \\
\hline & & & $4 / 21-5$ & +18.2 & $*$ & * & $*$ & & & & \\
\hline & & & $4 / 20-6$ & +14.8 & $*$ & $*$ & * & & & & $\begin{array}{l}\text { Sr-traces } \\
\text { in barite }\end{array}$ \\
\hline & & & $4 / 20-1$ & +26.6 & $*$ & $*$ & $*$ & & & & \\
\hline & & & $4 / 18$ & +26.5 & $*$ & * & * & & & & \\
\hline & & & $4 / 16 a$ & +9.6 & $*$ & $*$ & & & & & \\
\hline & & & 4/10a & +9.7 & $*$ & $*$ & $*$ & & & & \\
\hline & & & $4 / 9 b-5$ & +4.0 & $*$ & $*$ & * & & & & \\
\hline & & & $4 / 9 b-3$ & +8.4 & $*$ & $*$ & $*$ & & & & \\
\hline & & & $4 / 9-8$ & +9.1 & $*$ & * & & & & & \\
\hline & & & $4 / 9-6$ & 10.4 & $*$ & $*$ & & & & & \\
\hline & & & $4 / 6-5$ & +14.6 & $*$ & & & & & & \\
\hline Open & & +3.0 & $4 / 6-1$ & & $*$ & & & & & & \\
\hline Open & $\rightarrow$ & -8.3 & $1 / 13$ & & $*$ & $*$ & $*$ & $5-20$ & $\begin{array}{l}\text { Xenomorph } \\
\text { pathes }\end{array}$ & & $\begin{array}{l}\text { Co-bearing } \\
\text { Fe-sulfide }\end{array}$ \\
\hline Open & $\begin{array}{l}\text { Hydr } \\
\text { effect? }\end{array}$ & -14.7 & $1 / 12$ & & $*$ & * & * & & $\mathrm{Eq}$ & & $\begin{array}{l}\text { As-bearing } \\
\text { pyrite }\end{array}$ \\
\hline
\end{tabular}

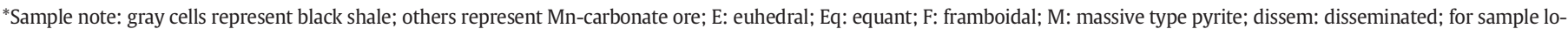
cation see Fig. 2. 

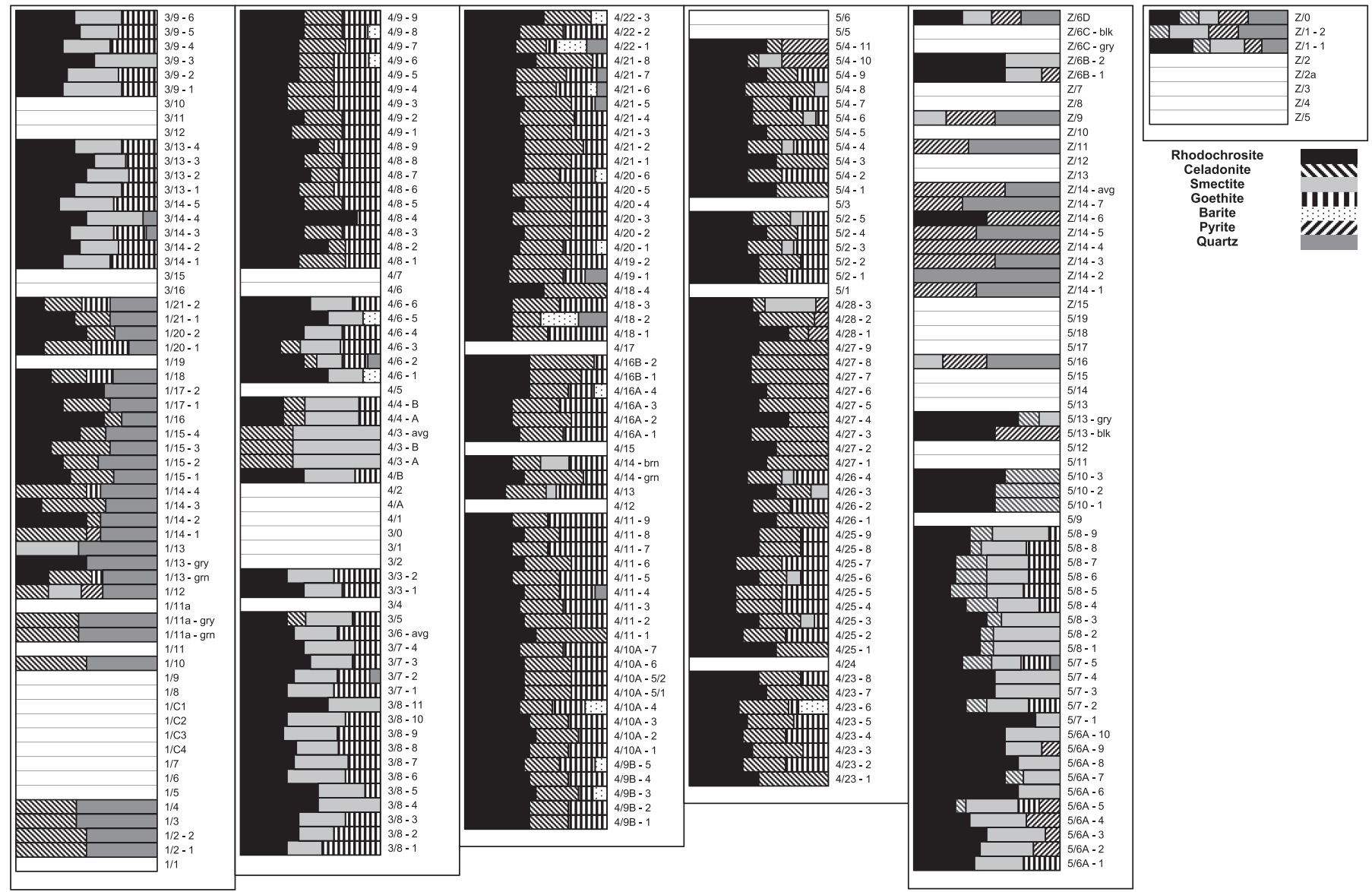

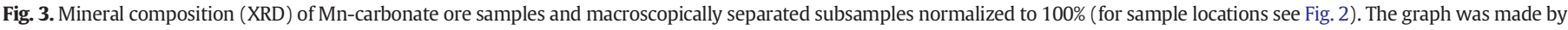
coding the estimated quantity of selected minerals (graphics by Gergely Rózsás, Pázmány Péter University). Key: gry - gray; grn - green; brn - brown; blk — black; avg - average.

remains of siliceous plankton such as Radiolaria as in Úrkút (Dehairs et al., 1980; Bishop, 1988; Polgári et al., 2012a). In Cenozoic marine sediments, barite mineralization occurs in the opal-CT and clinoptilolite transition, whereas the chalcedony-rich beds are poor in barite (Stamatakis and Hein, 1993). The Lower Jurassic Úrkút deposit contains only authigenic quartz with a negligible detrital quartz component.

Although most of the main Mn carbonate ore bed is free of pyrite, the barite-bearing zone has a unique distribution. The lower green part of the main ore bed is quartz-rich (30 wt.\%; Hahn, 2009; strong diagenetic quartz formation, profile 1, Figs. 2-3), and contains considerable amounts of celadonite reflecting suboxic formation and early diagenetic conditions, but the rhodochrosite and goethite contents are low. Owing to the fact that the $\mathrm{Mn}$ mineralization was microbially-mediated (Polgári et al., 2012a), and that the goethite is the mineralized remains of microbial mats (Polgári et al., 2012b), the organic matter content in this lower green part of the section is low which explains the absence of barite. The middle brown part of the main ore bed was a dense biomat system that existed under suboxic conditions and aided the anoxic/ anaerobic diagenetic formation of nontronite without sulfate reduction and pyrite formation (Polgári et al., 2013, Figs. 2-3). These conditions were probably too anoxic for barite formation, and the silica content is low in this part of the section (2 wt.\%; Hahn, 2009). The brown ore section contains the remnants of Mn-oxide "proto ore", which could not transform to rhodochrosite via early diagenesis in the absence of sufficient organic material. The barite-bearing upper green part of main ore bed also has low silica content ( 2 wt.\%; Hahn, 2009), but the organic material content was enough to lead to barite mineralization. The formation and diagenetic conditions based on clay mineralogy reflect suboxic conditions (Polgári et al., 2013). The gray top part of main ore bed is strongly pyritiferous, and thus the conditions were not favorable for barite formation.

\subsection{Genetic and paleoenvironmental considerations}

Manganese carbonate formation results from suboxic diagenetic reduction of Mn oxide by organic matter (e.g. Okita et al., 1988; Polgári et al., 1991).

Comparing our results with data from the Molango (Mexico) and Taojiang (China) Mn-carbonate microbialites reported by Okita and Shanks (1992) indicate strong similarities. The Mn-free rocks (black shale zones) in which pyrite is abundant are characterized by depleted $\delta^{34} S$-values typical of microbially-modulate pyrite formation with very similar average data in the three deposits ( $-24.1 \%$ for Molango; $-23.6 \%$ for TaoJiang; and $-22.4 \%$ for Úrkút-b2). Manganese-carbonate zones that are relatively poor in pyrite exhibit strong ${ }^{34} \mathrm{~S}$-enrichments. There are also some marked differences between the three deposits. The Molango Mn-carbonate samples (rhodochrosite, Mn-calcite + rhodochrosite and Mn-calcite) have $\delta^{34} \mathrm{~S}$ values that average about $-2.3 \%$ with a maximum of $+19.7 \%$. Taojiang has average $\delta^{34} \mathrm{~S}$ values of $+1.9 \%$ o with a maximum at $+24.5 \%$, compared to the average $\delta^{34} \mathrm{~S}$ for Úrkút of $+8.8 \%$ o with a maximum of $+35.2 \%$. The Mn-carbonate ore is also characterized by low total sulfide content, which may be the result of: (i) oxidizing conditions; (ii) influx of sulfate-deficient fresh water; (iii) re-oxidation and loss of metastable sulfides (MnS, FeS; Aller and Rude, 1988); or (iv) closed-system diagenesis in a system having low sulfate concentrations (Okita and Shanks, 1992). Based on Mn-enrichment processes, we consider oxidizing conditions (scenario i) as the most probable, but the 

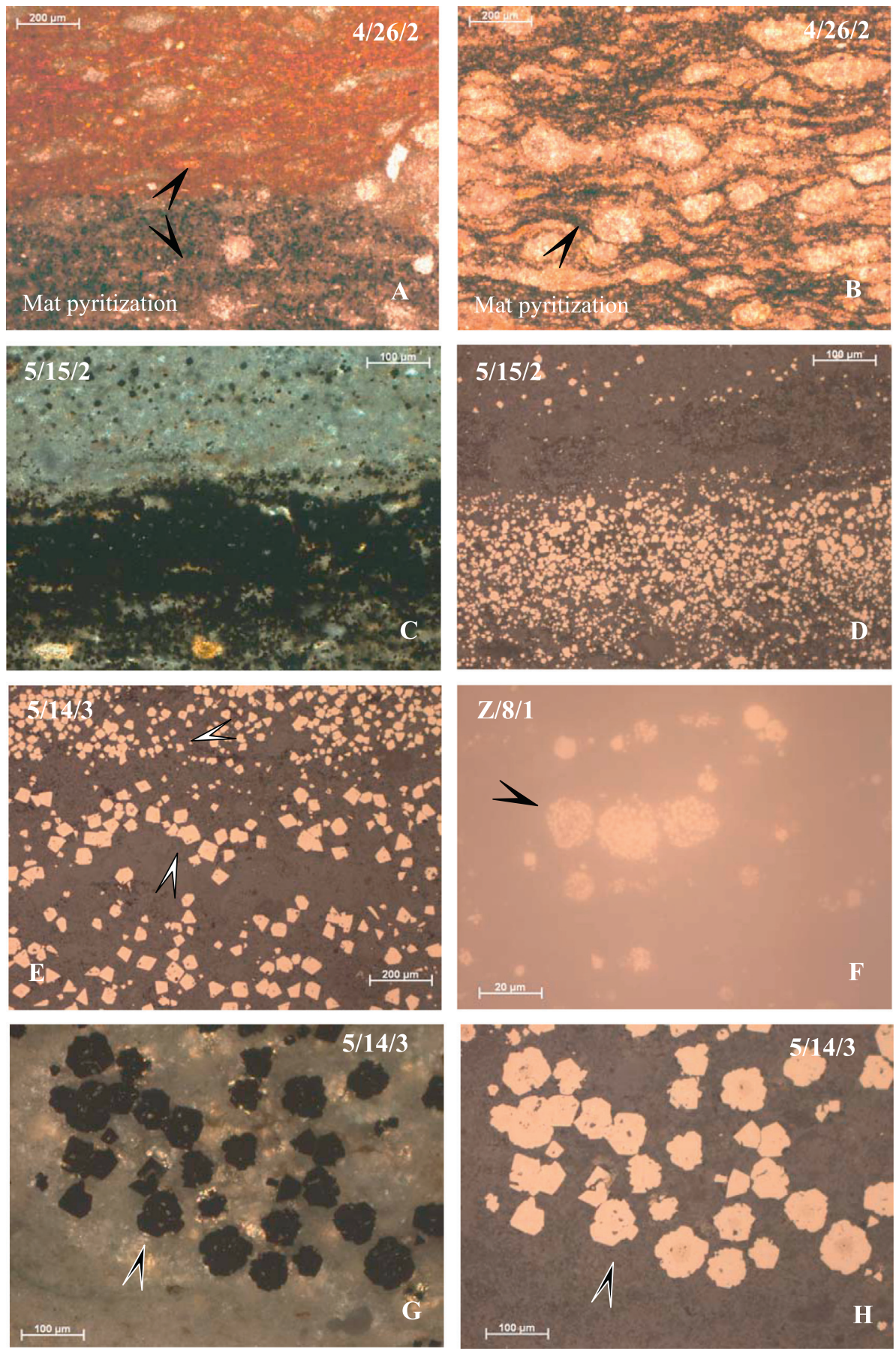

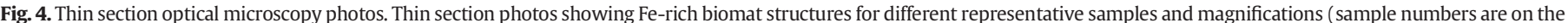

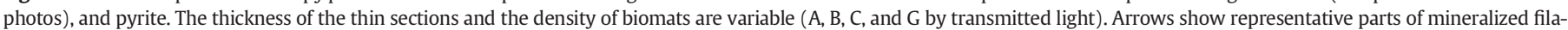

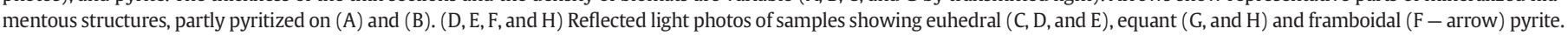
(D) Reflected light photo of $(C)$; $(H)$ reflected light photo of $(G)$. For sample locations see Fig. 2.

re-oxidation and loss of metastable sulfides (scenario ii) as well as closed-system diagenesis in a system having low sulfate concentrations (scenario iii) cannot be ruled out. Fresh water input can be excluded as all three deposits were formed in normal marine conditions.

As for what triggered the onset of Mn accumulation, distal hydrothermal discharge, and/or change of Eh conditions are plausible mechanisms.

The gray top part of the main ore bed is rich in pyrite, which also accompanies changes to the texture of the ore to coarse euhedral rhodochrosite and equant pyrite (Fig. 5B). We view this as evidence for some external pore fluid migration perhaps from distal hydrothermal influx. This conclusion is also supported by scarce occurrence of Cd-bearing
ZnS. Conditions were not favorable for barite formation here, but at some horizons the Sr content of barite, as well as enrichments in $\mathrm{Co}_{\text {, }}$ $\mathrm{Ni}$ and As in sulfides, point to the role of occasional hydrothermal input.

\section{Conclusions}

A whole profile mineralogical, trace element and isotopic study of a microbially-mediated Mn-carbonate ore at the Úrkút locality in central Hungary were undertaken to elucidate its petrogenesis and paleoenvironmental setting. Sulfur isotopes and trace elements were measured in the pyrite-bearing parts of the Úrkút microbialites. These 

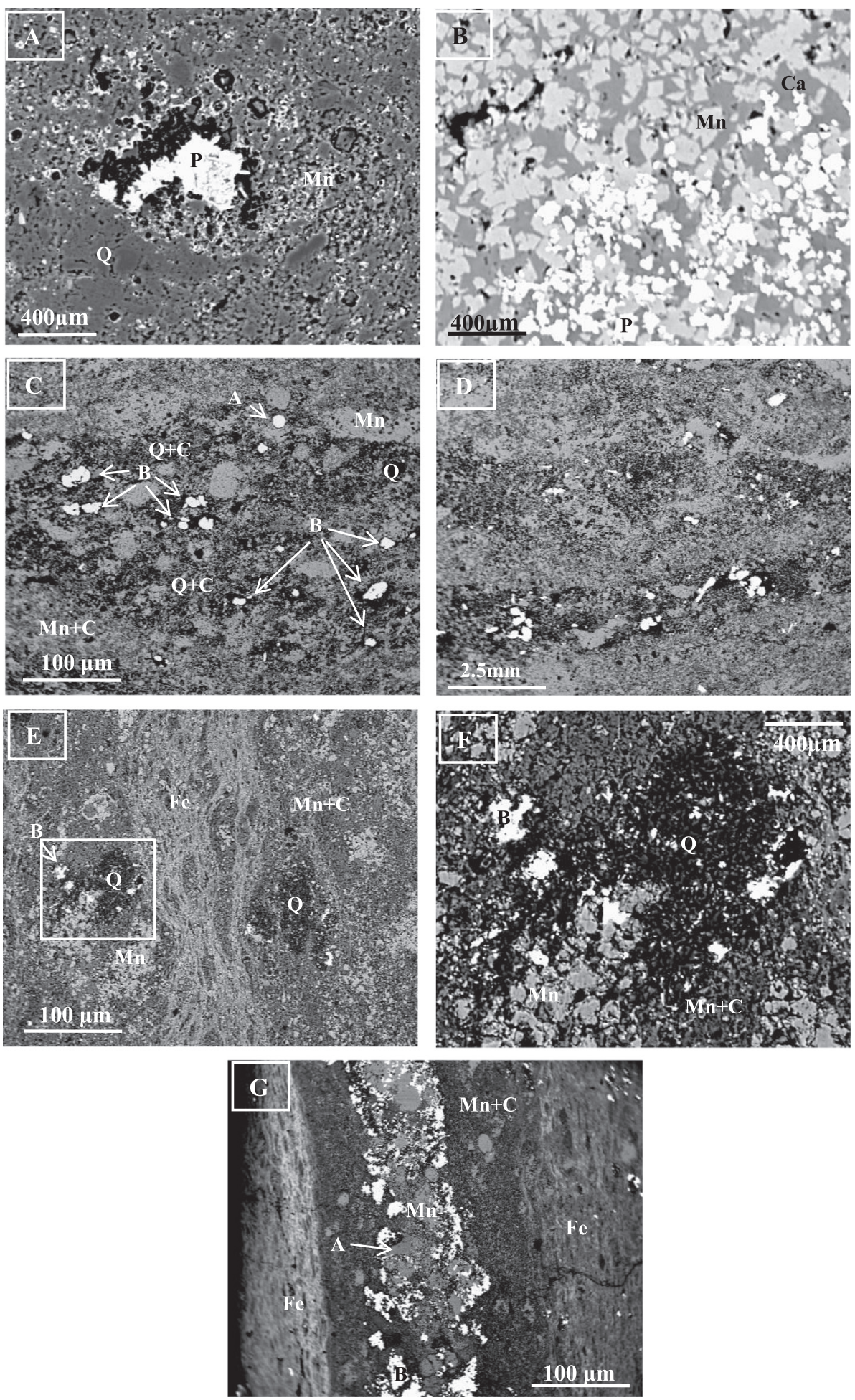

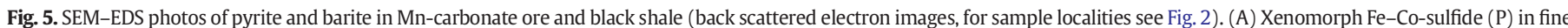

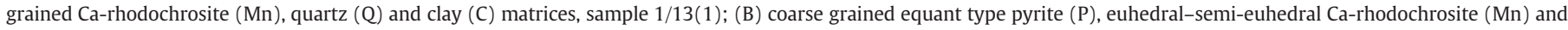

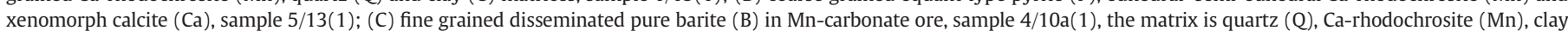

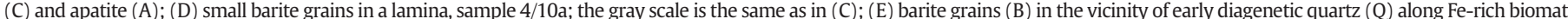

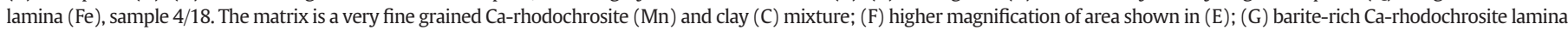
with apatite grain (A) between Fe-rich biomat laminae (Fe) and clay-rich Ca-rhodochrosite matrix. The barite is associated with quartz (dark-black phases), sample 4/22.

were documented to contain all main pyrite morphotypes, and the distribution of euhedral and framboidal types in the ore profile points to later diagenetic sulfate reduction zones, whereas the equant pyrite types occur at the contact zone of the organic-rich (black shale) and
Mn-carbonate ore horizons. The size of framboids supports diagenetic formation in a sulfate reduction zone under an oxic water column.

Measured $\delta^{34} \mathrm{~S}$ values up section show that the Úrkút paleosedimentary system acted as an open system over most of its black 


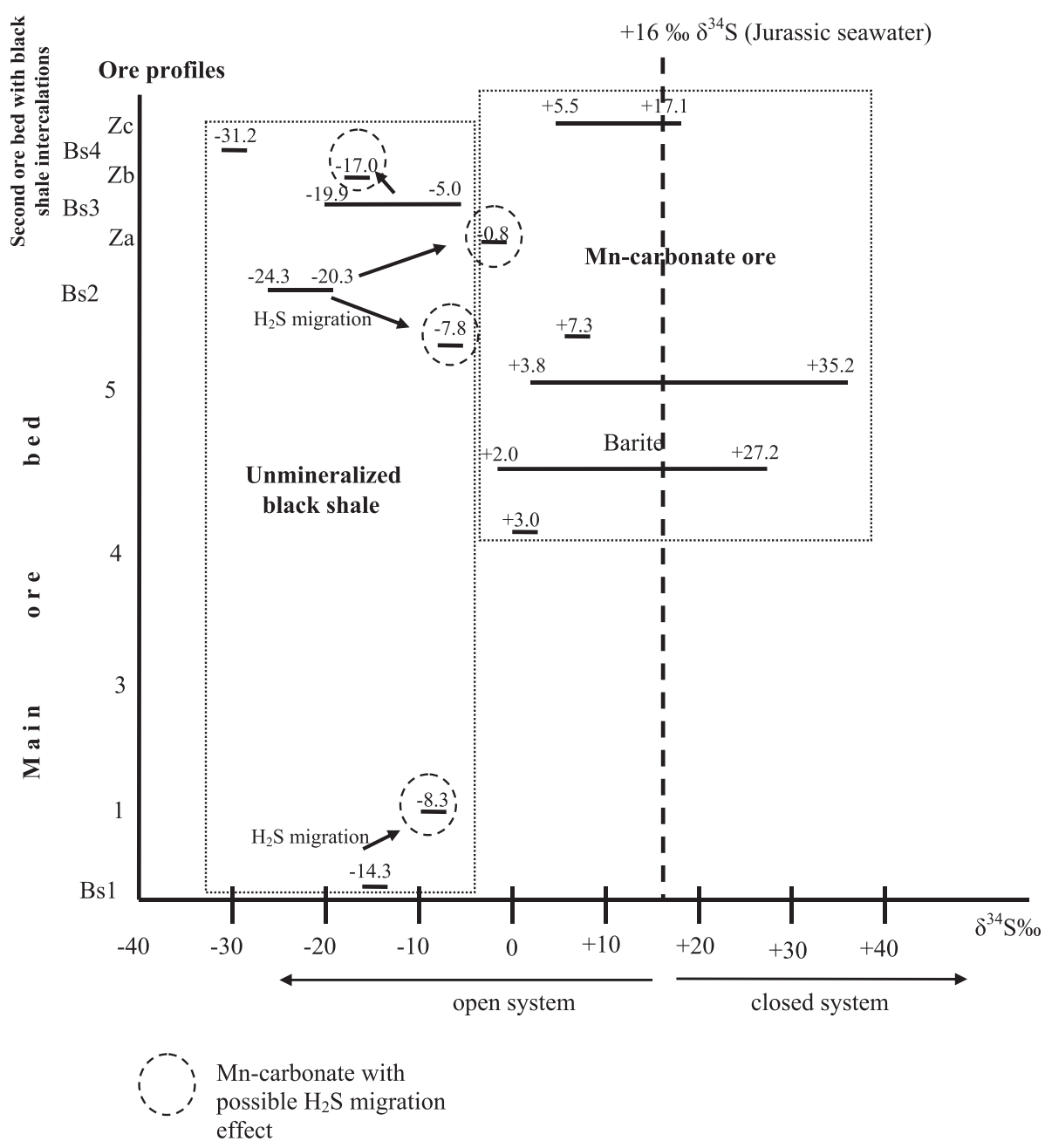

Bs1,2,3,4: black shale intervals

Fig. 6. Sulfur isotope distribution of barite and pyrite in the black shale-hosted Mn-carbonate deposit, Úrkút.

shale accumulation time and early diagenesis. Heavier $\delta^{34} S$ values in ore zones compared to contemporaneous Jurassic seawater indicate that only in ore horizons were semi-closed/closed conditions reached. Based on our analysis, the equant type pyrite most probably formed from external pore fluid migration subsequent to deposition. The most important factor that influenced the sulfur isotopic composition of sedimentary pyrites is the rate of sediment accumulation, which was high in the Úrkút depositional setting.

Barite occurs in the lower to middle part of the main ore bed, with a $\delta^{34} \mathrm{~S}$ between +2.0 and $+27.2 \%$, the average value is $+14.2 \%$. Given that Jurassic seawater $\delta^{34} \mathrm{~S}$ was around $+16 \%$, barite formation most likely happened under microbially mediated semi-closed/closed system conditions during later diagenesis. Barite is a common authigenic constituent of marine sedimentary formations in the form of disseminated small grains as found in Úrkút, enriched in lenses or layers, and commonly associated with biogenic debris. Hydrothermal input also played a role because $\mathrm{Fe}$ and $\mathrm{Mn}$ contents are very high ( $\mathrm{Mn}-\mathrm{Fe}$ ore), and vein filling $\mathrm{Sr}$-bearing barite is present. A clear association exists between barite and organic matter. The source of Ba was dominantly from the decomposition of organic matter derived from plankton and other organisms and the diagenesis of biogenic silica.

Despite the fact that most of the main Mn-carbonate ore bed is pyrite free, the barite-bearing zone has a unique distribution. The lower green part of the main ore bed is rich in quartz, and contains considerable celadonite that we interpret to represent suboxic formation and early diagenetic conditions, but the rhodochrosite and goethite contents of these layers are low. The low organic matter content in this lower green part could explain why barite is absent from this part of the section. The middle brown part of the main ore bed formed from a dense biomat under suboxic to anoxic/anaerobic conditions without sulfate reduction and associated pyrite formation. In addition to the low silica content, these conditions were probably too anoxic for barite formation. Furthermore, the brown ore contains remnants of a Mn-oxide "proto ore", which could not transform to rhodochrosite via early diagenesis in the absence of sufficient organic material. The barite-bearing upper green part of the main ore bed likewise has low silica content, but the organic material content was high enough to facilitate barite mineralization. The gray top part of the main ore bed is strongly pyritiferous, where the conditions were not favorable for barite formation.

In terms of paleoenvironment, the Mn-carbonate microbialites formed via suboxic diagenetic reduction of Mn-oxide by organic matter. Sub-oxic conditions too oxidizing to support sulfate reduction were evoked because of the conspicuous scarcity of pyrite and an abundance of oxidized Fe mineralization in the form of goethitic Fe-rich biomats within the Mn-carbonate.

Our results for Úrkút compare well with previous studies of the analogous Molango (Mexico) and Taojiang (China) localities described in Okita and Shanks (1992).

Cycles of onset and termination of Mn-carbonate production can be related to Mn supply by distal hydrothermal discharge, and/or change 
in Eh; sulfide crystal habit and trace element contents ( $\mathrm{Co}, \mathrm{Ni}, \mathrm{Zn}, \mathrm{Cd}$ and As) bolster the view that distal hydrothermal fluids variably affected the nature of deposition in the Úrkút microbialites.

\section{Acknowledgments}

The study was supported by Hungarian Science Foundation (OTKA-NKTH no. K 68992) to M.P. We thank Alexandra Müller for thin section preparation, and Máté Szabó for SEM-EDS measurements. A substantial portion of this manuscript was completed while S.J.M. held a Distinguished Research Professorship in Budapest at the Research Center for Astronomy and Earth Sciences of the Hungarian Academy of Sciences. We thank the careful reviews and constructive suggestions provided by the anonymous reviewers, and editorial handling by D. Nance.

\section{References}

Aller, R.C., Rude, P.D., 1988. Complete oxidation of solid phase sulphides by manganese and bacteria in anoxic marine sediments. Geochimica et Cosmochimica Acta 52, 751-765.

Bárdossy, G., Bottyán, L., Gadó, P., Griger, Á., Sasvári, J., 1980. Automated quantitative phase analysis of bauxites. American Mineralogist 65, 135-141.

Berner, R.A., 1980. Early Diagenesis - A Theoretical Approach. Princeton Univ. Press, Princeton (241 pp.).

Beukes, N.J., 1983. Palaeoenvironmental setting of iron-formations in the depositional basin of the Transvaal Supergroup, South Africa. In: Trendall, A.F., Morris, R.C. (Eds.), Iron Formation: Facts and Problems. Elsevier, Amsterdam, pp. 131-209.

Bishop, J.K.B., 1988. The barite-opal organic carbon association in oceanic particulate matter. Nature 332, 341-343.

Boström, K., Kraemer, T., Gartner, S., 1973. Provenance and accumulation rates of opaline silica Al, Ti, Fe, Mn, Cu, Ni and Co in pelagic sediments. Chemical Geology 11, 123-148.

Calvert, S.E., Pedersen, T.F., 1993. Geochemistry of recent oxic and anoxic sediments: implications for the geological record. Marine Geology 113, 67-88.

Clark, S.H.B., Mosier, E.L., 1989. Barite nodules in Devonian shale and mudstone of western Virginia. United States Geological Survey Bulletin 1880 (30 pp.).

Clark, S.H.B., Gallagher, M.J., Poole, F.G., 1990. World barite resources: a review of recent production patterns and a genetic association. Minerals, Materials and Industry: International Mining and Metallurgy Congress 14th, pp. 175-184.

Claypool, G.E., Holser, W.T., Kaplan, I.R., Sakai, H., Zak, I., 1980. The age curves of sulfur and oxygen isotopes in marine sulfate and their mutual interpretation. Chemical Geology $28,199-260$

Cruickshank, M.J., 1974. Mineral resources potential of continental margins. In: Burk, C.A Drake, C.L. (Eds.), The Geology of Continental Margins. Springer-Verlag, New York, pp. 965-1000.

Dehairs, F., Chesselet, R., Jedwab, J., 1980. Discrete suspended particles of barite and the barium cycle in the open ocean. Earth and Planetary Science Letters 49, 528-550.

Fan, D., Ye, J., Yin, L., Zhang, R., 1999. Microbial processes in the formation of the Sinian Gaoyan manganese carbonate ore. Sichuan Province, China, Ore Geology Reviews 15 (1-3), 79-95.

Force, E.R., Cannon, W.F., 1988. Depositional model for shallow-marine manganese deposits around black shale basins. Economic Geology 83 (1), 93-117.

Géczy, B., 1973. The Lower Jurassic ammonite faunas of the Southern Bakony (Transdanubia, Hungary). Ann. Univ. Sci. Bp. Sect. Geol. 17 pp. 181-190.

Hahn, T., 2009. Mineralogy, Cement Stratigraphy and Geochemistry of Manganese Ores and Host Rocks of the Toarcian Úrkút Deposit, Hungary. Technical University Bergakademie Freiberg, Germany (MSc dissertation, 84 pp.).

Hámor, T., 1994. The occurrence and morphology of sedimentary pyrite. Acta Geologica Hungarica 37 (1-2), 153-181.

Hámor, T., Hertelendi, E., 1991. Relationship between the early diagenetic evolution of sediment and the delta ${ }^{34} \mathrm{~S}$ values of sedimentary iron sulfides. Bulletin of the Hungarian Geological Society 121, 133-151.

Hein, J.R., Bolton, B.R., Nziengui, P., McKirdy, D., Frakes, L., 1989. Chemical, isotopic and lithologic associations within the Moanda Manganese Deposit, Gabon. Abstracts. 28th International Geologic Congress, Washington DC, pp. 2-47.
Holland, H.D., 1978. The chemistry of the atmosphere and oceans. Wiley Interscience, New York.

Hudson, J.D., 1982. Pyrite in ammonite-bearing shales from the Jurassic of England and Germany. Sedimentology 29, 639-667.

Koski, R.A., Hein, J.R., 2004. Stratiform barite deposits in the Roberts Mountains Allochthon, Nevada: a review of potential analogs in modern sea-floor environments. In: Bliss, James D., Moyle, Phillip R., Long, Keith R. (Eds.), Bulletin 2209-H, Contributions to Industrial-minerals Research. U.S. Geological Survey. U.S. Department of the Interior, pp. 1-17 (http://pubs.usgs.gov/bul/b2209-h/b2209h.pdf).

Leventhal, J.S., 1983. An interpretation of carbon and sulphur relationships in Black Sea sediments as indicators of environments of deposition. Geochimica et Cosmochimica Acta 47, 133-138.

Maynard, J.B., 2010. The chemistry of manganese ores through time: a signal of increasing diversity of earth-surface environments. Economic Geology 105 (3), 535-552.

Maynard, J.B., Okita, P.M., 1991. Bedded barite deposits in the United States, Canada, Germany, and China: two major types based on tectonic settings. Economic Geology 86, 364-376.

Murowchick, J.B., Barnes, H.L., 1987. Effects of temperature and degree of supersaturation on pyrite morphology. American Mineralogist 72, 1241-1250.

Okita, P.M., Shanks III, W.C., 1988. $\delta^{13} \mathrm{C}$ and $\delta^{34} \mathrm{~S}$ trends in sedimentary manganese deposit, Molango (Mexico) and Taojiang (China): evidence for mineralization in closed system. Absts., International Association for Sedimentologists. Symposium on Sedimentology Related to Mineral Deposits. Beijing, pp. 188-189.

Okita, P.M., Shanks, W.C., 1992. Origin of stratiform sediment-hosted manganese carbonate ore deposits: examples from Molango, Mexico, and Taojiang, China. Chemical Geology 99, 139-164.

Okita, P.M., Maynard, J.B., Spiker, E.C., Force, E.R., 1988. Isotopic evidence for organic matter oxidation by manganese reduction in the formation of stratiform manganese carbonate ore. Geochimica et Cosmochimica Acta 52, 2679-2685.

Polgári, M., 1993. Manganese geochemistry reflected by black shale formation and diagenetic processes - model of formation of the carbonatic manganese ore of Úrkút. Special Series of Hungarian Geological Institute. Karpati Publish House, Uzhgorod (211 pp.).

Polgári, M., Okita, P.M., Hein, J.R., 1991. Stable isotope evidence for the origin of the Úrkút manganese ore deposit, Hungary. Journal of Sedimentary Petrology 61 (3), 384-393.

Polgári, M., Dobosi, G., Horváth, P., Rálischné Felgenhauer, E., Vigh, T., 2003. As-bearing pyrite at Úrkút and in the Jurassic layers of borehole Iharosberény-I. Bulletin of the Hungarian Geological Survey 133 (4), 69-475 (in Hungarian with English abstract).

Polgári, M., Hein, J.R., Vigh, T., Szabó-Drubina, M., Fórizs, I., Bíró, L., Müller, A., Tóth, L. 2012a. Microbial processes and the origin of the Úrkút manganese deposit, Hungary. Ore Geology Reviews 47, 87-109.

Polgári, M., Hein, J.R., Tóth, A.L., Pál-Molnár, E., Vigh, T., Bíró, L., Fintor, K., 2012b. Microbia action formed Jurassic Mn-carbonate ore deposit in only a few hundred years (Úrkút, Hungary). Geology 40, 903-906.

Polgári, M., Hein, J.R., Németh, T., Pál-Molnár, E., Vígh, T., 2013. Celadonite and smectite formation in the Úrkút Mn-carbonate ore deposit (Hungary). Sedimentary Geology 294, 157-163.

Raiswell, R., 1982. Pyrite texture, isotopic composition and the availability of iron. American Journal of Science 282, 1244-1263.

Rothewell, R.G., 1989. Barite. In: Rothewell, R.G. (Ed.), Minerals and Mineraloids in Marine Sediments. Elsevier, Amsterdam, pp. 42-46.

Stamatakis, M.G., Hein, J.R., 1993. Origin of barite in Tertiary marine sedimentary rocks from Lefkas Island, Greece. Economic Geology 88, 91-103.

Sweeney, R.E., Kaplan, I.R., 1973. Diagenetic sulfate reduction in marine sediments. Marine Chemistry 9, 165-174.

Szabó, Z., Grasselly, Gy, 1980. Genesis of manganese oxide ore in the Úrkút basin, Hungary. In: Varentsov, I.M., Grasselly, Gy (Eds.), Geology and Geochemistry o Manganese. vol. 2. Akadémiai Kiadó, Budapest, pp. 223-236.

Vető, I., Demény, A., Hertelendi, E., Hetényi, M., 1997. Estimation of primary productivity in the Toarcian Tethys - a novel approach based on TOC, reduced sulphur and manganese contents. Palaeogeography Palaeoclimatology Palaeoecology 132, 355-371.

Wignall, P.B., Newton, R., 1998. Pyrite framboid diameter as a measure of oxygen deficiency in ancient mudrocks. American Journal of Science 298 (7), 537-552.

Wilkin, R.T., Barnes, H.L., Brantley, S.L., 1996. The size distribution of framboidal pyrite in modern sediments: an indicator of redox conditions. Geochimica et Cosmochimica Acta 60 (20), 3897-3912.

Wilkin, R.T., Arthur, M.A., Dean, W.E., 1997. History of water-column anoxia in the Black Sea indicated by pyrite framboid size distributions. Earth and Planetary Science Letters 148 (3), 517-525. 